\title{
The Dynamic between Municipal Revenue Sources and the State-Local Relationship in New England
}

\author{
by Richard F. Dye
}

\begin{abstract}
This working paper was written for the New England Public Policy Center's third annual conference: "The Dynamic between Municipal Revenue Sources and the State-Local Relationship in New England". It relies on data from the U.S. Census to examine the dynamic between municipal revenues and the state-local relationship in New England. The analysis shows that-compared with the nation as a whole-municipal governments in New England rely very heavily on the property tax. They also have limited or no access to local-option revenues such as sales taxes, and they rely less on fees and other nontax sources.
\end{abstract}

Although some research has shown that the local property tax can help counter fluctuations in state aid, Massachusetts, Rhode Island, and Maine all limit the percent by which local governments may increase their property tax collections from one year to the next. Municipalities in these states are more vulnerable to changes in state aid, and more bound by constraints on other revenue sources.

New England states and municipal governments will face enormous fiscal pressures as their populations age dramatically and they face higher pension and health care costs. This analysis suggests the need for policymakers to consider new local revenue sources and state aid formulas.

Richard F. Dye is a professor with the Institute of Government and Public Affairs at the University of Illinois at Chicago. He is also a visiting fellow at the Lincoln Institute of Land Policy in Cambridge, MA and the Ernest Johnson Professor of Economics Emeritus at Lake Forest College in Illinois. The author thanks Bo Zhao for valuable comments on earlier drafts.

The views expressed in this paper are those of the author and do not reflect positions of the Federal Reserve Bank of Boston or the Federal Reserve System. 


\section{Introduction}

Municipal governments in New England are under fiscal stress. That is cause for concern in the region because municipal governments are more important in New England states than in other states. Town governments—largely unique to New England—provide services that counties or special-purpose districts provide in other states. Municipal governments in New England are also much more likely to provide public education, while the rest of the nation relies largely on independent school districts.

State and local governments are inextricably linked, and the state-municipal relationship is particularly important in New England because of the large municipal responsibility for providing public services. All local governments are the legal creations of state governments, which specify, constrain, and sometimes mandate the activities local governments can undertake, including which revenue sources they can rely on. Local governments also rely heavily on state grants-in-aid as a major source of revenue.

State and local governments are further linked because they compete for the same tax-bearing capacity—that is, the income—of their mutual residents, and often for the same specific revenue sources, such as property taxes. State and local governments are also beset by many of the same cyclical forces that affect revenue collections and expenditure responsibilities, and they often share the same underlying growth rates that affect their regions.

This working paper relies on data from the U.S. Census Bureau to examine the dynamic between municipal revenues and the state-local relationship in New England, compared with that dynamic in the country as a whole. First, to reveal the importance of 
municipal government in New England, Section II looks at the structure of local government in New England states compared with that in the rest of the nation.

Section III then presents census data on revenue sources for state and local government combined, and then for the entire local government sector, in both New England and the nation as a whole. This analysis shows that the local government sector in New England relies more heavily on the property tax than does that sector across the country, and that its second most important source of revenue is state aid.

Section IV focuses on municipal government: the type of local government most common in New England. This analysis shows that compared with the rest of the nation, municipal governments in New England have limited access to local revenue sources other than the property tax. They have no local-option sales taxes and no local-option income taxes, and they rely much less on fees and other non-tax revenue sources than do municipal governments in other states. That is partly because state governments in New England often do not give municipal governments access to revenue sources other than property taxes.

The revenues of state governments fluctuate cyclically, and they declined dramatically across the country earlier in this decade. Many states responded by cutting grants-in-aid to local governments, or by restraining increases in that aid. Section V shows that local governments in many states-including those in some New England statesresponded with above-trend increases in property taxes. Thus the stability of the property tax is an important counter to fluctuations in state revenues and state aid.

Section VI looks at another key state-municipal link: state limits on the local property tax. Massachusetts, Rhode Island, and Maine all have state-imposed limits on the 
percentage by which local governments may increase property tax collections from one year to the next. Municipal governments in states with such caps are more vulnerable to changes in state aid, and more strongly affected by constraints on other local revenue sources.

Section VII argues that states across the country, and especially in New England, will face enormous fiscal pressures as the population ages over the next several decades. According to the 2000 census, 12.4 percent of the U.S. population was 65 or older. Projections show that by 2030, 19.7 percent of the population will be 65 or older. All the New England states are projected to be above that national-average share, and Vermont and Maine are projected to be significantly above-at 24.4 and 26.5 percent, respectively.

An aging population means higher Medicaid costs for states. An aging population also means that bills for unfunded state and local pension liabilities and retiree health costs will come due. These changes will probably exert a greater fiscal impact on state governments than on municipal governments. However, when states are under pressure, they often cut aid to local government.

Although the analysis ends there, the hope is that these findings will spur active consideration of policy responses to the fiscal plight of municipal governments in New England.

\section{The Structure of Local Government in New England versus the Nation}

The structure of local government in New England states evolved earlier than that in most other states, and continues to differ. The U.S. Census of Governments gathers information on the revenues and expenditures of all local governments in each state every five years, and categorizes them by five types of government: counties, municipalities, 
townships, independent school districts, and other special-purpose districts. Table 1 gives the share of total local government revenue for each of these five groups for the United States overall, and for the New England states.

Table 1: Share of Total Local Government General Revenue by Type of Local Government, 2002 Census

\begin{tabular}{|c|c|c|c|c|c|c|c|}
\hline & U.S. & CT & ME & MA & NH & RI & VT \\
\hline County & $25.2 \%$ & $0.0 \%$ & $3.1 \%$ & $0.9 \%$ & $8.8 \%$ & $0.0 \%$ & $0.3 \%$ \\
\hline Municipal & $28.0 \%$ & $37.3 \%$ & $26.4 \%$ & $44.2 \%$ & $27.9 \%$ & $50.3 \%$ & $9.6 \%$ \\
\hline Township or Town & $3.3 \%$ & $54.4 \%$ & $39.6 \%$ & $36.5 \%$ & $19.3 \%$ & $40.6 \%$ & $19.8 \%$ \\
\hline Special District & $9.1 \%$ & $5.1 \%$ & $6.9 \%$ & $11.6 \%$ & $2.5 \%$ & $4.7 \%$ & $4.6 \%$ \\
\hline School District & $34.4 \%$ & $3.2 \%$ & $24.0 \%$ & $6.8 \%$ & $41.5 \%$ & $4.4 \%$ & $65.7 \%$ \\
\hline
\end{tabular}

Source: U.S. Bureau of the Census, "Local Summary Tables by Type of Government and State: 2001-02"

This table shows that county governments collect one-quarter of local revenues in the nation as a whole, but do not exist at all in Connecticut and Rhode Island, and are of trivial fiscal importance in Massachusetts and Vermont. In Maine and New Hampshire, counties account for quite small shares of local government: 3.1 and 8.8 percent, respectively. In most states outside New England, counties provide general government services to rural areas and urbanized areas that are not incorporated as municipalities.

Twenty states in the Northeast and Midwest have what the census categorizes as "township or town" governments. Outside New England, a township is usually a sub-county area that provides a specified set of services not provided by the county or incorporated municipalities. New England states are partitioned into towns that provide general government services to both densely and sparsely populated areas within their boundaries. 
Table 1 shows that in the United States overall, towns or townships collect only 3.3 percent of local government revenues. That small figure is the average for three very different types of states: 30 states with zero township government, roughly 10 states where townships provide a limited set of services to mostly rural areas, and New England and several other states where town or township governments provide general government services to both urban and rural areas. The town or township share of total local government spending in the New England states ranges from just under 20 percent in New Hampshire and Vermont, to around 40 percent in Massachusetts, Maine, and Rhode Island, to more than 50 percent in Connecticut.

New England states have far fewer incorporated municipalities_cities, villages, or boroughs - than most other states: fewer than 50 each. Given that almost all areas of each New England state were historically designated as under the purview of a general-purpose town government, newly urbanized areas had less reason to incorporate as municipalities to set boundaries for service delivery, tax collection, and regulatory control. The fiscal share of municipalities in New England states ranges from 10 percent in Vermont to 50 percent in Rhode Island. The percentage depends a lot on which type of government pays for public schools.

Nationally, the largest share of local government revenue, 34.4 percent, goes to independent school districts: separate units of government that provide education services. The alternative, sometimes called dependent school districts - where expenditures for elementary and secondary education fall under the purview of general-purpose governments such as towns and municipalities-is more common in New England. The notable exception is Vermont, where entirely independent school districts account for almost two-thirds of local 
government revenue. ${ }^{1}$ In Connecticut, Massachusetts, and Rhode Island, town and municipal governments are the primary providers of school services, with independent school districts accounting for only a small fraction of school expenditures. Maine and New Hampshire have a mixture of independent and dependent school districts.

Finally, special-purpose governments, such as independent library districts and metropolitan service agencies, account for about 9 percent of local government revenues nationwide. Massachusetts—with large "authorities" providing water, transit, port, and airport services in the Boston metropolitan area-is above average in choosing this form of government, but the other New England states are significantly below average. The predominance in New England of general-purpose town governments with predefined coverage of the landscape probably explains the low revenue share for this type of government.

\section{Comparing Local Government Revenues across States and Over Time}

This section examines revenues for the state and local government sector combined, and then for the entire local government sector-all five types of local governments combined—to enable meaningful cross-state comparisons.

Such comparisons are difficult because states differ in how they assign certain expenditure functions to the local versus state government sector. Hawaii, for example, is radically different from other states, in that its state government runs the elementary and secondary school system. In the other 49 states, local governments provide education, but

\footnotetext{
${ }^{1}$ Vermont school districts are generally contiguous with town borders and are often referred to as "town" schools, but they are legally autonomous from town government, and thus are treated as separate by the Census Bureau.
} 
the states provide pass-through financing to local school districts. Therein lies a second complication in making comparisons across states-varying degrees of state aid to local governments.

Third, as noted, states differ in how they assign expenditure functions to generalpurpose governments, such as towns and municipalities, versus special-purpose governments, such as library districts or independent school districts. Elementary and secondary education is by far the largest category of local government spending, representing two-fifths of the total. ${ }^{2}$

A final complication in examining the state and local fiscal picture concerns the timing and level of detail available in standardized data from the U.S. Census Bureau. Data for the combined local government sector are available for every year-most recently for the fiscal year ending in 2005. However, as noted, the census provides data on revenues and spending for each of the five types of local government only every five years, most recently for the fiscal year ending in 2002.

Table 2 (page 8) shows the major sources of revenue for state and local government—including counties, municipalities, townships, independent school districts, and other special-purpose districts-for the United States as a whole, and for each of the six New England states, in $2005 .^{3}$

\footnotetext{
${ }^{2}$ In 2003, local governments spent 40.3 percent of their revenues directly on elementary and secondary education (U.S. Bureau of the Census, "State and Local Government Finances," accessed using the State \& Local Government Finance Data Query System of the Urban Institute-Brookings Institution Tax Policy Center).

${ }^{3}$ For a more detailed analysis of the structure, yield, and relative reliance on different state and local taxes in New England states, see Murray 2006. Even though Murray's focus is the state of Maine, almost all his tables also provide detailed information on the other New England states.

For a sophisticated method of looking at state and local government tax capacity and expenditure need across states, see Ylimaz et al. 2006. For a very readable application of that method to New England states, see Nagowski 2007. According to this measure of fiscal capacity relative to need, Connecticut, Massachusetts, and
} 
This table shows that total state and local government revenues in the entire United

States averaged $\$ 6,816$ per capita in 2005. All the New England states, with the exception of

New Hampshire, were above the U.S. average.

Table 2: State and Local Government Revenue by Source and State, 2005

(Total General Revenue in Real 2005 Dollars per Capita; Details as Share of Total General Revenue)

\begin{tabular}{|c|r|r|r|r|r|r|r|}
\hline & \multicolumn{1}{|c|}{ U.S. } & \multicolumn{1}{c|}{$\mathrm{CT}$} & $\mathrm{ME}$ & $\mathrm{MA}$ & $\mathrm{NH}$ & $\mathrm{RI}$ & $\mathrm{VT}$ \\
\hline General Revenue & $\$ 6,816$ & $\$ 7,890$ & $\$ 7,475$ & $\$ 7,636$ & $\$ 5,903$ & $\$ 7,589$ & $\$ 7,752$ \\
\hline Intergovernmental Revenue & $21.7 \%$ & $16.1 \%$ & $26.9 \%$ & $18.7 \%$ & $21.1 \%$ & $25.9 \%$ & $27.2 \%$ \\
\hline From Federal Government & $21.7 \%$ & $16.1 \%$ & $26.9 \%$ & $18.7 \%$ & $21.1 \%$ & $25.9 \%$ & $27.2 \%$ \\
\hline From State Government & & & & & & & \\
\hline Own-Source General Revenue & $78.3 \%$ & $83.9 \%$ & $73.1 \%$ & $81.3 \%$ & $78.9 \%$ & $74.1 \%$ & $72.8 \%$ \\
\hline Taxes & $54.3 \%$ & $68.4 \%$ & $53.0 \%$ & $58.5 \%$ & $56.0 \%$ & $55.2 \%$ & $53.4 \%$ \\
\hline Property & $16.6 \%$ & $25.9 \%$ & $21.8 \%$ & $21.0 \%$ & $34.4 \%$ & $22.3 \%$ & $21.9 \%$ \\
\hline General Sales & $13.0 \%$ & $11.8 \%$ & $9.5 \%$ & $7.9 \%$ & & $10.4 \%$ & $6.5 \%$ \\
\hline Selective Sales & $6.0 \%$ & $6.7 \%$ & $4.3 \%$ & $4.2 \%$ & $9.1 \%$ & $6.7 \%$ & $9.8 \%$ \\
\hline Individual Income & $11.9 \%$ & $18.2 \%$ & $13.2 \%$ & $19.7 \%$ & $0.9 \%$ & $12.2 \%$ & $10.4 \%$ \\
\hline Corporate Income & $2.1 \%$ & $2.1 \%$ & $1.4 \%$ & $2.7 \%$ & $6.2 \%$ & $1.4 \%$ & $1.4 \%$ \\
\hline Other Taxes & $4.6 \%$ & $3.6 \%$ & $2.7 \%$ & $3.0 \%$ & $5.4 \%$ & $2.2 \%$ & $3.4 \%$ \\
\hline Charges and Fees & $15.3 \%$ & $8.5 \%$ & $10.5 \%$ & $11.0 \%$ & $13.1 \%$ & $9.1 \%$ & $11.2 \%$ \\
\hline Misc. General Revenue & $8.8 \%$ & $7.0 \%$ & $9.7 \%$ & $11.7 \%$ & $9.9 \%$ & $9.8 \%$ & $8.2 \%$ \\
\hline
\end{tabular}

Source: U.S. Bureau of the Census, State and Local Government Finances.

Note: Blank $=$ none; $0.0 \%=$ less than $0.05 \%$.

Intergovernmental revenue from the federal government accounted for 21.7 percent of general revenues for the state and local government sector. In the New England states, federal aid ranged from a low of 16.1 percent in Connecticut to a high of 27.2 percent in 
Vermont. Income differences between states explain much of that variation, as many federal aid programs are linked to a state's per capita income.

Table 3 provides supplementary information on income and federal aid in the New England states relative to the nation. The first two columns show the negative correlation between per capita income and per capita federal aid in each New England state. The table also shows that, in terms of population, Massachusetts is of average size, while the other New England states are relatively small. ${ }^{4}$

Table 3: Income, Federal Aid, and Population for New England States, 2005

\begin{tabular}{|l|c|c|c|}
\hline \multicolumn{1}{|c|}{ State } & $\begin{array}{c}\text { Personal Income } \\
\text { per capita in State } \\
\text { (as percent of Nation) }\end{array}$ & $\begin{array}{c}\text { Federal Aid to State and } \\
\text { Local Government } \\
\text { per capita in State } \\
\text { (as percent of Nation) }\end{array}$ & $\begin{array}{c}\text { Population } \\
\text { in State } \\
\text { (millions) }\end{array}$ \\
\hline Connecticut & $137 \%$ & $86 \%$ & 3.5 \\
\hline Maine & $89 \%$ & $136 \%$ & 1.3 \\
\hline Massachusetts & $126 \%$ & $97 \%$ & 6.4 \\
\hline New Hampshire & $110 \%$ & $84 \%$ & 1.3 \\
\hline Rhode Island & $102 \%$ & $133 \%$ & 1.1 \\
\hline Vermont & $95 \%$ & $143 \%$ & 0.6 \\
\hline
\end{tabular}

Source: U.S. Census, State and Local Government Finances.

Table 2 shows that all the New England states rely more on property taxes than the national average -16.6 percent—as a share of general revenue for the state and local government sector. Maine, Massachusetts, Rhode Island, and Vermont all fall in the 21-22 percent range. At 29.5 percent, Connecticut relies heavily on the property tax. In New

\footnotetext{
${ }^{4}$ Population differences do not present a problem in interpreting the statistics in this working paper, because they are calculated in per capita terms or as a percentage share of a state total.
} 
Hampshire, property taxes account for more than 34 percent of total general revenue for the combined state and local government sector-by far the largest share in the nation.

All six New England states rely less on sales taxes than the national average share of 19.0 percent for general and selective sales taxes together. New Hampshire has no general sales tax.

As relatively high-income states, Connecticut and Massachusetts take advantage of that by relying heavily on individual income taxes. New Hampshire again stands out, this time in its low reliance on individual income taxes: in this state, this narrowly defined state tax applies only to interest and dividends, not to wages and salaries. Corporate income taxes represent only 2.1 percent of state and local general revenues nationwide, and five of the New England states are within a fairly narrow range of that average. New Hampshire receives 6.2 percent of state and local revenues from the corporate income tax.

Charges include tuition at state and community colleges, hospital receipts, highway tolls, sewer and water fees, and the like. Charges represent 15.3 percent of all state and local revenues nationwide. All the New England states are below that average, ranging from 8.5 percent in Connecticut to 13.1 in New Hampshire. (See more on that subject below.)

Miscellaneous general revenue includes special assessments, interest income, lottery receipts, and the like. These revenues account for 8.8 percent of all state and local revenues nationwide. In New England, these revenues range from 7.0 percent in Connecticut, to just under 10 percent in Maine, New Hampshire, and Rhode Island, to 11.7 percent in Massachusetts. Table 4 (page 11) concentrates on revenues of the local government sector alone (combining municipalities, counties, independent school districts, and other special districts). This table shows that the New England states are all below the national average 
in per capital local government revenue. A comparison of the first rows of Tables 2 and 4 shows that the local government sector is 57.4 percent $(\$ 3,914 / \$ 6,816)$ of the combined state and local government sector nationwide. New England relies relatively more on state as opposed to local government to provide services.

Table 4: Local Government General Revenue by Source and State, 2005 (Total General Revenue in Real 2005 Dollars per Capita; Details as Share of Total General Revenue)

\begin{tabular}{|c|r|r|r|r|r|r|r|}
\hline & U.S. & \multicolumn{1}{c|}{$\mathrm{CT}$} & $\mathrm{ME}$ & $\mathrm{MA}$ & $\mathrm{NH}$ & $\mathrm{RI}$ & $\mathrm{VT}$ \\
\hline General Revenue & $\$ 3,914$ & $\$ 3,654$ & $\$ 3,016$ & $\$ 3,667$ & $\$ 3,201$ & $\$ 3,130$ & $\$ 2,959$ \\
\hline Intergovernmental Revenue & $38.9 \%$ & $33.1 \%$ & $31.6 \%$ & $41.3 \%$ & $33.4 \%$ & $33.9 \%$ & $70.1 \%$ \\
\hline From Federal Government & $4.5 \%$ & $3.5 \%$ & $3.2 \%$ & $5.5 \%$ & $3.2 \%$ & $4.2 \%$ & $2.9 \%$ \\
\hline From State Government & $34.4 \%$ & $29.6 \%$ & $28.4 \%$ & $35.8 \%$ & $30.2 \%$ & $29.7 \%$ & $67.2 \%$ \\
\hline Own-Source General Revenue & $61.1 \%$ & $66.9 \%$ & $68.4 \%$ & $58.7 \%$ & $66.6 \%$ & $66.1 \%$ & $29.9 \%$ \\
\hline Taxes & $38.6 \%$ & $57.2 \%$ & $54.0 \%$ & $45.5 \%$ & $54.9 \%$ & $55.7 \%$ & $18.0 \%$ \\
\hline Property & $27.9 \%$ & $55.9 \%$ & $53.0 \%$ & $43.8 \%$ & $54.0 \%$ & $54.1 \%$ & $16.9 \%$ \\
\hline General Sales & $4.3 \%$ & & & & & & $0.2 \%$ \\
\hline Selective Sales & $1.9 \%$ & $0.0 \%$ & $0.0 \%$ & $0.6 \%$ & & $0.3 \%$ & $0.2 \%$ \\
\hline Individual Income & $1.8 \%$ & & & & & & \\
\hline Corporate Income & $0.4 \%$ & & & & & & \\
\hline Other Taxes & $2.3 \%$ & $1.2 \%$ & $1.0 \%$ & $1.1 \%$ & $0.9 \%$ & $1.3 \%$ & $0.6 \%$ \\
\hline Charges and Fees & $16.0 \%$ & $6.8 \%$ & $10.7 \%$ & $9.9 \%$ & $8.6 \%$ & $7.6 \%$ & $7.5 \%$ \\
\hline Misc. General Revenue & $6.5 \%$ & $3.0 \%$ & $3.6 \%$ & $3.2 \%$ & $3.1 \%$ & $2.9 \%$ & $4.3 \%$ \\
\hline
\end{tabular}

Source: U.S. Bureau of the Census, State and Local Government Finances. Note: Blank $=$ none; $0.0 \%=$ less than $0.05 \%$.

Intergovernmental revenue from state government represents 34.4 percent of local government revenues nationwide. States channel most of these funds through their school aid formula. Putting aside Vermont, to which we will return in a moment, we see that 
Massachusetts is slightly above the national average in posting 34.4 percent of local revenue from state aid, while the other four New England states are below the national average.

Local government in Connecticut, Maine, New Hampshire, and Rhode Island—in

the 53-56 percent range—obtains twice the national average share of 27.9 percent from local property taxes, while Massachusetts, at 43.8 percent, is still well above average. Vermont, with only 16.9 percent reliance on the local property tax, is significantly below average. Both its high state aid share -67.2 percent, almost twice the national average—and its low property tax share reflect the state's assumption of a large portion of previously local property taxes in 1998, and the redistribution of those revenues in a more equalizing school aid formula. ${ }^{5}$ In the past decade, New Hampshire, too, simultaneously reduced local property taxes, increased state property taxes, and increased state aid to local schools. ${ }^{6}$

Table 4 reinforces the finding from Table 2 that New England governments rely much less on charges than do local governments in other states.

The focus on local governments in Table 4 reveals a clearer pattern regarding miscellaneous general revenue than did Table 2. In Table 4, the national average share for this type of local government revenue is only 6.5 percent. However, the share in all the New England states is well below that figure, ranging from 2.9 percent in Rhode Island to 4.3 percent in Vermont.

\footnotetext{
${ }^{5}$ For a review of the 1998 and 2003 school finance reforms in Vermont, see Saas 2006.

${ }^{6}$ There is some arbitrariness in assigning the property tax to the state or local level, especially in a state that mandates a local property tax, or links it to the state aid formula. Kenyon (2003) argues that there is little effective difference between Kansas, which requires a minimum local property tax, and New Hampshire, where a state property tax is collected and mostly retained at the local level, because of the state aid formula. However, while there may be little effective difference to the local taxpayer and school district budget if state property taxes are returned in the form of aid, there is a big census reporting difference. For a review of the 1999 school finance reforms in New Hampshire, see Gottlob and Kenyon 2005.
} 
To identify changes in state and local government revenue over the previous decade, the next two tables present the same information for 1995 as the previous two did for 2005. A comparison of Tables 2 and 5 shows that real per capita state and local revenue rose significantly from 1995 to 2005-by more than 20 percent in the United States overall, and ranging from more than 15 percent in Connecticut to more than 35 percent in Maine.

Table 5: State and Local Government General Revenue by Source and State, 1995 (Total General Revenue in Real 2005 Dollars per Capita; Details as Share of Total General Revenue)

\begin{tabular}{|c|r|r|r|r|r|r|r|}
\hline & \multicolumn{1}{|c|}{ U.S. } & \multicolumn{1}{c|}{$\mathrm{CT}$} & $\mathrm{ME}$ & $\mathrm{MA}$ & $\mathrm{NH}$ & $\mathrm{RI}$ & $\mathrm{VT}$ \\
\hline General Revenue & $\$ 5,628$ & $\$ 6,827$ & $\$ 5,505$ & $\$ 6,377$ & $\$ 5,027$ & $\$ 5,957$ & $\$ 5,961$ \\
\hline Intergovernmental Revenue & $19.6 \%$ & $17.1 \%$ & $23.3 \%$ & $20.1 \%$ & $18.7 \%$ & $26.3 \%$ & $27.1 \%$ \\
\hline From Federal Government & $19.6 \%$ & $17.1 \%$ & $23.3 \%$ & $20.1 \%$ & $18.7 \%$ & $26.3 \%$ & $27.1 \%$ \\
\hline From State Government & & & & & & & \\
\hline Own-Source General Revenue & $80.4 \%$ & $82.9 \%$ & $76.7 \%$ & $79.9 \%$ & $81.3 \%$ & $73.7 \%$ & $72.9 \%$ \\
\hline Taxes & $56.5 \%$ & $68.2 \%$ & $57.3 \%$ & $59.2 \%$ & $57.3 \%$ & $55.7 \%$ & $52.7 \%$ \\
\hline Property & $17.4 \%$ & $25.7 \%$ & $23.8 \%$ & $20.7 \%$ & $36.7 \%$ & $24.1 \%$ & $23.6 \%$ \\
\hline General Sales & $13.7 \%$ & $13.4 \%$ & $12.2 \%$ & $8.1 \%$ & $0.0 \%$ & $9.7 \%$ & $6.3 \%$ \\
\hline Selective Sales & $6.6 \%$ & $7.6 \%$ & $5.2 \%$ & $4.3 \%$ & $11.9 \%$ & $6.6 \%$ & $8.1 \%$ \\
\hline Individual Income & $11.8 \%$ & $14.0 \%$ & $12.0 \%$ & $19.5 \%$ & $0.8 \%$ & $11.2 \%$ & $9.1 \%$ \\
\hline Corporate Income & $2.7 \%$ & $3.9 \%$ & $1.2 \%$ & $3.9 \%$ & $3.7 \%$ & $1.7 \%$ & $1.8 \%$ \\
\hline Other Taxes & $4.3 \%$ & $3.6 \%$ & $3.0 \%$ & $2.6 \%$ & $4.2 \%$ & $2.4 \%$ & $3.8 \%$ \\
\hline Charges and Fees & $14.7 \%$ & $7.6 \%$ & $10.3 \%$ & $10.9 \%$ & $11.9 \%$ & $8.1 \%$ & $11.7 \%$ \\
\hline Misc. General Revenue & $9.2 \%$ & $7.0 \%$ & $9.1 \%$ & $9.8 \%$ & $12.1 \%$ & $9.8 \%$ & $8.5 \%$ \\
\hline
\end{tabular}

Source: U.S. Bureau of the Census, State and Local Government Finances. Note: Blank $=$ none; $0.0 \%=$ less than $0.05 \%$. 
Table 6: Local Government General Revenue by Source and State, 1995

(Total General Revenue in Real 2005 Dollars per Capita; Details as Share of Total General Revenue)

\begin{tabular}{|c|c|c|c|c|c|c|c|}
\hline & U.S. & CT & ME & MA & $\mathrm{NH}$ & RI & VT \\
\hline General Revenue & $\$ 3,255$ & $\$ 3,046$ & $\$ 2,436$ & $\$ 2,901$ & $\$ 2,521$ & $\$ 2,416$ & $\$ 2,443$ \\
\hline Intergovernmental Revenue & $38.3 \%$ & $32.0 \%$ & $32.6 \%$ & $38.0 \%$ & $14.6 \%$ & $32.8 \%$ & $32.3 \%$ \\
\hline From Federal Government & $3.9 \%$ & $3.5 \%$ & $3.3 \%$ & $6.1 \%$ & $2.6 \%$ & $5.4 \%$ & $10.0 \%$ \\
\hline From State Government & $34.4 \%$ & $28.4 \%$ & $29.3 \%$ & $31.8 \%$ & $12.0 \%$ & $27.3 \%$ & $22.3 \%$ \\
\hline Own-Source General Revenue & $61.7 \%$ & $68.0 \%$ & $67.4 \%$ & $62.0 \%$ & $85.4 \%$ & $67.2 \%$ & $67.7 \%$ \\
\hline Taxes & $38.7 \%$ & $58.2 \%$ & $52.8 \%$ & $46.8 \%$ & $74.0 \%$ & $59.6 \%$ & $57.3 \%$ \\
\hline Property & $28.7 \%$ & $57.6 \%$ & $51.9 \%$ & $45.5 \%$ & $73.2 \%$ & $58.9 \%$ & $56.6 \%$ \\
\hline General Sales & $4.1 \%$ & & & & & & \\
\hline Selective Sales & $1.8 \%$ & $0.0 \%$ & $0.1 \%$ & $0.4 \%$ & & $0.1 \%$ & $0.2 \%$ \\
\hline Individual Income & $1.8 \%$ & & & & & & \\
\hline Corporate Income & $0.3 \%$ & & & & & & \\
\hline Other Taxes & $1.8 \%$ & $0.7 \%$ & $0.8 \%$ & $0.9 \%$ & $0.7 \%$ & $0.7 \%$ & $0.5 \%$ \\
\hline Charges and Fees & $15.9 \%$ & $6.3 \%$ & $11.3 \%$ & $12.3 \%$ & $8.3 \%$ & $5.6 \%$ & $6.9 \%$ \\
\hline Misc. General Revenue & $7.2 \%$ & $3.5 \%$ & $3.3 \%$ & $3.0 \%$ & $3.1 \%$ & $2.0 \%$ & $3.5 \%$ \\
\hline
\end{tabular}

Source: U.S. Bureau of the Census, State and Local Government Finances.

Note: Blank $=$ none; $0.0 \%=$ less than $0.05 \%$.

As a share of general revenue, federal aid went up and state and local taxes went down by about 2 percentage points in the United States overall. However, changes in the shares of these revenue sources in individual New England states are noticeably different from the U.S. average. General sales tax revenues as a share of total revenues in Maine fell from 12.2 percent in 1995 to 9.5 percent in 2005. Individual income tax revenues as a share of total revenues in Connecticut rose from 14.0 to 18.2 percent.

A comparison of Tables 4 and 6 reveals that in the United States as a whole, real local revenues per capita grew over the decade in each of the categories, while the shares of 
both state aid and local taxes remained constant. Individual New England states saw more variation. Massachusetts (from 31.8 to 35.8 percent) and Rhode Island (from 27.3 to 29.7 percent) saw sizable increases in the state-aid share of local government revenue. The major policy shifts in New Hampshire (from 12.0 to 30.2 percent) and Vermont (from 22.3 to 67.2 percent) noted above led to enormous increases in the state aid share.

In New Hampshire, local property taxes as a share of total revenues declined from 73.2 percent in 1995 to 54.0 percent in 2005. In Vermont, the local property tax share fell from 56.6 percent of total revenues in 1995 to 16.9 percent in 2005. In both cases, because the state assumed what had been local property taxes, the decline in property tax shares for the combined state and local government sector was much smaller-from 36.7 percent to 34.4 percent for New Hampshire, and from 23.6 percent to 21.9 percent in Vermont.

\section{Revenue Sources for Municipal Governments Only}

To highlight trends in the revenues and expenditures of municipal governmentsthe dominant form of local government in New England-the next tables combine the census figures for "township and town" and "incorporated municipal." (As noted, the U.S. Census of Governments provides detail on revenue sources by type of local government only in quinquennial years, most recently for 2002.) 
Table 7: Municipal Share of Total Local Government Sector for Selected Revenue and Expenditure Categories, 2002

\begin{tabular}{|l|c|c|c|c|c|c|c|}
\hline & U.S. & CT & $\mathrm{ME}$ & $\mathrm{MA}$ & $\mathrm{NH}$ & $\mathrm{RI}$ & $\mathrm{VT}$ \\
\hline Intergovernmental Revenue from State & $19.5 \%$ & $96.2 \%$ & $55.6 \%$ & $76.5 \%$ & $29.6 \%$ & $94.9 \%$ & $6.5 \%$ \\
\hline Property Tax Revenue & $28.6 \%$ & $98.3 \%$ & $74.7 \%$ & $98.0 \%$ & $52.4 \%$ & $98.6 \%$ & $58.0 \%$ \\
\hline Direct General Expenditure & $31.7 \%$ & $93.2 \%$ & $62.6 \%$ & $86.1 \%$ & $48.1 \%$ & $91.0 \%$ & $29.8 \%$ \\
\hline $\begin{array}{l}\text { Elementary and Secondary Educ. } \\
\text { Expenditure }\end{array}$ & $10.8 \%$ & $94.4 \%$ & $50.7 \%$ & $85.5 \%$ & $22.5 \%$ & $92.4 \%$ & $0.0 \%$ \\
\hline
\end{tabular}

Source: U.S. Bureau of the Census, "Local Summary Tables by Type of Government and State: 2001-02" Note: Census government types "municipal" and "township" are combined in the numerator and "county," "school district" and "special district" are added to them in the denominator.

Table 7 shows the municipal share of the total local government sector for two revenue and two expenditure categories. This table reinforces what we already concluded from Table 1: that municipal governments in five New England states account for considerably more than the national average share of total state-aid revenue, property tax revenue, total spending, and school spending. The exception is Vermont, where independent school districts, not municipal governments, make all of the education expenditures and receive most of the state aid.

Table 8 (page 17) presents the full detail available for municipal revenue sources from the 2002 Census of Governments. This information confirms some of the points made earlier: that property taxes are by far the major source of revenue for municipal governments in New England, and that state aid is by far the second largest source of revenue. 
Table 8: Municipal Revenue Sources by State, 2002

(Total General Revenue in 2005 Dollars per Capita; Details as Share of Total General Revenue)

\begin{tabular}{|c|c|c|c|c|c|c|c|}
\hline & U.S. & $\mathrm{CT}$ & $\mathrm{ME}$ & $\mathrm{MA}$ & $\mathrm{NH}$ & $\mathrm{RI}$ & VT \\
\hline General Revenue & $\$ 1,206$ & $\$ 3,169$ & $\$ 1,982$ & $\$ 2,974$ & $\$ 1,394$ & $\$ 2,574$ & $\$ 788$ \\
\hline Intergovernmental Revenue & $29.1 \%$ & $31.6 \%$ & $26.1 \%$ & $37.4 \%$ & $27.6 \%$ & $33.1 \%$ & $17.3 \%$ \\
\hline From Federal Government & $4.9 \%$ & $1.1 \%$ & $0.5 \%$ & $2.4 \%$ & $3.9 \%$ & $2.1 \%$ & $4.1 \%$ \\
\hline From State Government & $21.6 \%$ & $30.2 \%$ & $24.4 \%$ & $34.9 \%$ & $22.2 \%$ & $30.8 \%$ & $12.2 \%$ \\
\hline From Local Government** & $2.6 \%$ & $0.3 \%$ & $1.2 \%$ & $0.1 \%$ & $1.6 \%$ & $0.1 \%$ & $1.1 \%$ \\
\hline General Revenue from Own Sources & $70.9 \%$ & $68.4 \%$ & $73.9 \%$ & $62.6 \%$ & $72.4 \%$ & $66.9 \%$ & $82.7 \%$ \\
\hline Taxes & $44.0 \%$ & $59.4 \%$ & $60.9 \%$ & $50.4 \%$ & $55.4 \%$ & $58.1 \%$ & $58.2 \%$ \\
\hline Property & $24.1 \%$ & $58.4 \%$ & $58.8 \%$ & $48.7 \%$ & $53.4 \%$ & $56.9 \%$ & $56.1 \%$ \\
\hline Sales and Gross Receipts & $11.1 \%$ & $0.0 \%$ & $0.2 \%$ & $0.8 \%$ & & $0.2 \%$ & $0.7 \%$ \\
\hline General Sales & $6.7 \%$ & & & & & & \\
\hline Selective Sales & $4.4 \%$ & $0.0 \%$ & $0.2 \%$ & $0.8 \%$ & & $0.2 \%$ & $0.7 \%$ \\
\hline Public Utilities & $2.7 \%$ & & $0.0 \%$ & & & & $0.3 \%$ \\
\hline Other Selective Sales & $1.5 \%$ & $0.0 \%$ & $0.2 \%$ & $0.8 \%$ & & $0.2 \%$ & $0.4 \%$ \\
\hline Individual Income & $4.0 \%$ & & & & & & \\
\hline Corporate Income & $0.9 \%$ & & & & & & \\
\hline Motor Vehicle License Taxes & $0.2 \%$ & & $1.1 \%$ & & & & \\
\hline Other Taxes & $3.6 \%$ & $0.9 \%$ & $0.8 \%$ & $0.9 \%$ & $2.0 \%$ & $1.1 \%$ & $1.3 \%$ \\
\hline Charges and Misc. General Revenue & $26.9 \%$ & $9.0 \%$ & $13.0 \%$ & $12.2 \%$ & $16.9 \%$ & $8.8 \%$ & $24.5 \%$ \\
\hline Current Charges & $17.4 \%$ & $5.7 \%$ & $9.0 \%$ & $9.2 \%$ & $12.1 \%$ & $5.5 \%$ & $17.4 \%$ \\
\hline Education & $0.2 \%$ & $0.9 \%$ & $0.9 \%$ & $0.9 \%$ & $0.6 \%$ & $0.7 \%$ & \\
\hline School Lunch Sales (gross) & $0.1 \%$ & $0.8 \%$ & $0.7 \%$ & $0.6 \%$ & $0.5 \%$ & $0.4 \%$ & \\
\hline Hospitals & $2.0 \%$ & $0.2 \%$ & $1.3 \%$ & $1.6 \%$ & & $0.0 \%$ & \\
\hline Highways & $0.4 \%$ & $0.0 \%$ & $0.0 \%$ & $0.0 \%$ & & $0.0 \%$ & $0.5 \%$ \\
\hline Airports & $1.8 \%$ & $0.0 \%$ & $0.7 \%$ & $0.1 \%$ & $1.8 \%$ & & $2.0 \%$ \\
\hline Parking Facilities & $0.4 \%$ & $0.3 \%$ & $0.1 \%$ & $0.2 \%$ & $0.5 \%$ & $0.0 \%$ & $1.3 \%$ \\
\hline Sea and Inland Port Facilities & $0.3 \%$ & $0.0 \%$ & $0.1 \%$ & $0.0 \%$ & & $0.1 \%$ & $0.0 \%$ \\
\hline Parks and Recreation & $1.1 \%$ & $0.6 \%$ & $0.5 \%$ & $0.3 \%$ & $0.6 \%$ & $0.5 \%$ & $1.1 \%$ \\
\hline Housing and Comm. Dev. & $0.5 \%$ & $0.1 \%$ & $0.1 \%$ & $0.1 \%$ & & $0.1 \%$ & $0.0 \%$ \\
\hline Sewerage & $6.0 \%$ & $1.8 \%$ & $2.8 \%$ & $3.8 \%$ & $4.6 \%$ & $2.2 \%$ & $8.1 \%$ \\
\hline Solid Waste Management & $1.9 \%$ & $0.4 \%$ & $0.4 \%$ & $0.5 \%$ & $1.1 \%$ & $0.1 \%$ & $0.9 \%$ \\
\hline Other Charges & $2.8 \%$ & $1.5 \%$ & $2.1 \%$ & $1.6 \%$ & $3.0 \%$ & $1.8 \%$ & $3.6 \%$ \\
\hline Miscellaneous General Revenue & $9.5 \%$ & $3.3 \%$ & $4.0 \%$ & $3.1 \%$ & $4.8 \%$ & $3.3 \%$ & $7.1 \%$ \\
\hline Interest Earnings & $4.1 \%$ & $1.1 \%$ & $1.8 \%$ & $0.9 \%$ & $1.8 \%$ & $0.7 \%$ & $2.1 \%$ \\
\hline Special Assessments & $0.7 \%$ & $0.2 \%$ & $0.0 \%$ & $0.0 \%$ & $0.0 \%$ & $0.2 \%$ & $0.5 \%$ \\
\hline Sale of Property & $0.2 \%$ & $0.1 \%$ & $0.0 \%$ & $0.0 \%$ & $0.3 \%$ & $0.2 \%$ & $0.1 \%$ \\
\hline Other Misc. General Rev. & $4.5 \%$ & $2.0 \%$ & $2.2 \%$ & $2.1 \%$ & $2.7 \%$ & $2.2 \%$ & $4.4 \%$ \\
\hline
\end{tabular}

Source: U.S. Bureau of the Census, "Local Summary Tables by Type of Government and State: 2001-02". Notes: Census government types "municipal" and "township" are combined. Blank = none; $0.0 \%=$ less than $0.05 \%$.

*Chance of very small errors since township to municipal transfers has not been netted out. 
However, local officials do not determine state aid, and property taxes are subject to a number of constraints. Table 8 therefore also sheds light on the extent to which municipal governments are tapping smaller revenue sources—or perhaps could. ${ }^{7}$

General sales taxes provide 6.7 percent of municipal revenues nationwide. No New England states have any local-option sales taxes.

Selective sales taxes provide 4.4 percent of total revenues, on average, for municipal governments in the United States. Most of this revenue comes from local taxes on public utilities. Only Vermont and Maine make any use of utilities taxes, and the amounts they collect are very small. All New England states rely less than the national average on nonutility selective sales taxes, such as those on hotels and motels.

Individual or corporate income taxes appear not to be a local option in any New England state. And only in Maine do municipalities collect local taxes on motor vehicle licenses.

All New England states show some municipal use of other taxes, but less than the national average. Such taxes include municipal death and gift taxes, taxes on documents and stock transfers, severance taxes, and taxes on land at a specified rate per acre (rather

\footnotetext{
${ }^{7}$ The comparison to the U.S. average to New England states for the smaller revenue sources is problematic. The national totals include a number of large cities whose states have allowed them much broader discretion to levy different types of taxes and charges than is available to most New England towns.

In a study of changes between 1977 and 2000 in the finances of a national sample of cities with populations greater than 100,000, Wallin (2005) found that more cities took more advantage of sales and income taxes where they had that option, and relied more heavily on fees and current charges. Wallin's sample included Bridgeport, Hartford, New Haven, Stamford, and Waterbury, CT; Boston, Cambridge, Fall River, New Bedford, Springfield, and Worcester, MA; Providence, RI; and no cities in Maine, New Hampshire, or Vermont.

Wallin also identified other several major trends. General expenditures grew more slowly over this period among cities than among other types of governments. Intergovernmental aid as a share of general revenues, particularly for schools, saw a net increase. And a major shift occurred in the source of intergovernmental aid, with state governments providing more and the federal government providing less.
} 
than on assessed value). (The census file used to construct Table 8 does not break out these types of taxes separately.)

Municipal governments in all states levy charges and fees for services or the use of facilities in a number of categories, shown in the table as "current charges." Municipal governments in all the New England states except Massachusetts collect less in charges per capita than the national average. Even Massachusetts collects less than the national average if current charges are measured as a share of total revenue. This below-average reliance on charges suggests some additional revenue-raising opportunities for municipal governments in New England.

It is hard to tell whether New England municipalities have additional opportunities for collecting miscellaneous general revenue. The "other" category, which is not broken out in the data file, includes items such as rents, dividends, prior-year adjustments, and payments in lieu of taxes.

The next two tables provide background information. Table 9 (page 20) shows how much municipal governments in the United States and the New England states spent per capita in 2002, along with shares for a number of specific categories. Table 10 (page 21) provides the same detail on municipal expenditures in 1997. 
Table 9: Municipal Expenditure Categories by State, 2002

(Total Direct General Expenditure in Real 2005 Dollars per Capita; Details as Share of Total Direct General Expenditure)

\begin{tabular}{|c|c|c|c|c|c|c|c|}
\hline & U.S. & $\mathrm{CT}$ & $\mathrm{ME}$ & $\mathrm{MA}$ & $\mathrm{NH}$ & $\mathrm{RI}$ & VT \\
\hline Direct General Expenditure & $\$ 1,178$ & $\$ 3,042$ & $\$ 1,721$ & $\$ 2,935$ & $\$ 1,371$ & $\$ 2,460$ & $\$ 753$ \\
\hline \multicolumn{8}{|l|}{ Education Services: } \\
\hline Elementary \& Secondary Ed. & $14.1 \%$ & $54.9 \%$ & $44.2 \%$ & $50.6 \%$ & $25.3 \%$ & $57.6 \%$ & $0.0 \%$ \\
\hline Higher Education & $0.2 \%$ & & & & & & \\
\hline Libraries & $1.2 \%$ & $1.2 \%$ & $1.0 \%$ & $1.2 \%$ & $1.4 \%$ & $1.0 \%$ & $2.6 \%$ \\
\hline \multicolumn{8}{|l|}{ Social Services Income Maint: } \\
\hline Public Welfare & $3.2 \%$ & $1.1 \%$ & $1.4 \%$ & $0.4 \%$ & $1.0 \%$ & $0.3 \%$ & $0.1 \%$ \\
\hline Hospitals & $3.3 \%$ & $0.3 \%$ & $1.6 \%$ & $3.7 \%$ & $0.0 \%$ & $0.0 \%$ & $0.0 \%$ \\
\hline Health & $2.0 \%$ & $1.3 \%$ & $0.8 \%$ & $0.6 \%$ & $1.3 \%$ & $0.1 \%$ & $1.3 \%$ \\
\hline \multicolumn{8}{|l|}{ Transportation } \\
\hline Highways & $8.4 \%$ & $4.2 \%$ & $8.6 \%$ & $3.6 \%$ & $9.7 \%$ & $3.0 \%$ & $28.9 \%$ \\
\hline Airports & $2.2 \%$ & $0.0 \%$ & $2.3 \%$ & $0.1 \%$ & $1.4 \%$ & & $1.6 \%$ \\
\hline Parking Facilities & $0.3 \%$ & $0.3 \%$ & $0.1 \%$ & $0.1 \%$ & $0.3 \%$ & $0.1 \%$ & $1.3 \%$ \\
\hline Sea and Inland Port Facilities & $0.4 \%$ & $0.0 \%$ & $0.2 \%$ & $0.0 \%$ & & $0.0 \%$ & $0.0 \%$ \\
\hline \multicolumn{8}{|l|}{ Public Safety: } \\
\hline Police Protection & $12.5 \%$ & $6.4 \%$ & $4.8 \%$ & $6.6 \%$ & $9.9 \%$ & $7.9 \%$ & $10.0 \%$ \\
\hline Fire Protection & $6.2 \%$ & $3.6 \%$ & $4.1 \%$ & $4.8 \%$ & $6.8 \%$ & $6.9 \%$ & $6.9 \%$ \\
\hline Correction & $0.9 \%$ & & $0.1 \%$ & $0.6 \%$ & & & \\
\hline Protective Inspection/Regul. & $0.9 \%$ & $0.2 \%$ & $0.2 \%$ & $0.6 \%$ & $0.4 \%$ & $0.3 \%$ & $0.1 \%$ \\
\hline \multicolumn{8}{|l|}{ Environment and Housing: } \\
\hline Natural Resources & $0.1 \%$ & & & $0.1 \%$ & $0.3 \%$ & & \\
\hline Parks and Recreation & $5.3 \%$ & $2.0 \%$ & $2.1 \%$ & $1.1 \%$ & $3.2 \%$ & $1.6 \%$ & $3.7 \%$ \\
\hline Housing and Comm. Dev. & $4.1 \%$ & $1.1 \%$ & $0.7 \%$ & $1.4 \%$ & $2.3 \%$ & $1.6 \%$ & $1.8 \%$ \\
\hline Sewerage & $6.4 \%$ & $2.4 \%$ & $2.7 \%$ & $2.8 \%$ & $4.2 \%$ & $2.2 \%$ & $9.4 \%$ \\
\hline Solid Waste Management & $3.5 \%$ & $1.9 \%$ & $3.3 \%$ & $1.9 \%$ & $3.8 \%$ & $1.6 \%$ & $2.6 \%$ \\
\hline \multicolumn{8}{|l|}{ Governmental Administration: } \\
\hline Financial Administration & $2.4 \%$ & $1.6 \%$ & $4.5 \%$ & $1.4 \%$ & $2.7 \%$ & $1.7 \%$ & $9.4 \%$ \\
\hline Judicial and Legal & $1.3 \%$ & $0.4 \%$ & $0.2 \%$ & $0.3 \%$ & $0.6 \%$ & $0.5 \%$ & $0.5 \%$ \\
\hline General Public Buildings & $1.4 \%$ & $1.0 \%$ & $1.1 \%$ & $1.8 \%$ & $1.4 \%$ & $0.9 \%$ & $0.8 \%$ \\
\hline $\begin{array}{l}\text { Other Governmental } \\
\text { Administration }\end{array}$ & $2.7 \%$ & $1.6 \%$ & $1.5 \%$ & $0.8 \%$ & $4.6 \%$ & $1.6 \%$ & $3.1 \%$ \\
\hline Interest on General Debt & $5.4 \%$ & $2.8 \%$ & $2.6 \%$ & $2.6 \%$ & $3.5 \%$ & $2.7 \%$ & $3.1 \%$ \\
\hline Other General Expenditure & $11.4 \%$ & $11.7 \%$ & $12.0 \%$ & $12.7 \%$ & $15.8 \%$ & $8.5 \%$ & $12.7 \%$ \\
\hline Intergovernmental Expenditure** & $3.3 \%$ & $3.7 \%$ & $11.1 \%$ & $7.1 \%$ & $1.0 \%$ & $2.1 \%$ & $0.6 \%$ \\
\hline
\end{tabular}

Source: U.S. Bureau of the Census, "Local Summary Tables by Type of Government and State: 2001-02". Notes: Census government types "municipal" and "township" are combined. Blank = none; $0.0 \%=$ less than $0.05 \%$.

*Chance of very small errors since township to municipal transfers has not been netted out. 
Table 10: Municipal Revenue Sources by State, 1997

(Total General Revenue in Real 2005 Dollars per Capita; Details as Share of Total General Revenue)

\begin{tabular}{|c|c|c|c|c|c|c|c|}
\hline & U.S. & $\mathrm{CT}$ & $\mathrm{ME}$ & MA & $\mathrm{NH}$ & $\mathrm{RI}$ & VT \\
\hline General Revenue & $\$ 1,108$ & $\$ 2,923$ & $\$ 1,814$ & $\$ 2,542$ & $\$ 1,213$ & $\$ 2,352$ & $\$ 750$ \\
\hline Intergovernmental Revenue & $27.8 \%$ & $29.5 \%$ & $23.6 \%$ & $36.2 \%$ & $14.1 \%$ & $29.3 \%$ & $16.0 \%$ \\
\hline From Federal Government & $4.8 \%$ & $1.4 \%$ & $1.4 \%$ & $2.2 \%$ & $1.7 \%$ & $1.5 \%$ & $2.1 \%$ \\
\hline From State Government & $20.6 \%$ & $27.9 \%$ & $21.8 \%$ & $33.9 \%$ & $11.7 \%$ & $27.4 \%$ & $12.7 \%$ \\
\hline From Local Government** & $2.4 \%$ & $0.3 \%$ & $0.4 \%$ & $0.0 \%$ & $0.6 \%$ & $0.4 \%$ & $1.3 \%$ \\
\hline General Revenue from Own Sources & $72.2 \%$ & $70.5 \%$ & $76.4 \%$ & $63.8 \%$ & $85.9 \%$ & $70.7 \%$ & $84.0 \%$ \\
\hline Taxes & $44.4 \%$ & $60.8 \%$ & $63.1 \%$ & $51.8 \%$ & $69.1 \%$ & $61.6 \%$ & $61.5 \%$ \\
\hline Property & $24.4 \%$ & $60.0 \%$ & $60.3 \%$ & $50.5 \%$ & $67.6 \%$ & $60.8 \%$ & $59.7 \%$ \\
\hline Sales and Gross Receipts & $11.0 \%$ & $0.0 \%$ & $0.5 \%$ & $0.5 \%$ & & $0.1 \%$ & $0.5 \%$ \\
\hline General Sales & $6.6 \%$ & & & & & & \\
\hline Selective Sales & $4.4 \%$ & $0.0 \%$ & $0.5 \%$ & $0.5 \%$ & & $0.1 \%$ & $0.5 \%$ \\
\hline Public Utilities & $2.6 \%$ & $0.0 \%$ & $0.0 \%$ & & & $0.0 \%$ & $0.4 \%$ \\
\hline Other Selective Sales & $1.8 \%$ & $0.0 \%$ & $0.4 \%$ & $0.5 \%$ & & $0.1 \%$ & $0.2 \%$ \\
\hline Individual Income & $4.4 \%$ & & & & & & \\
\hline Corporate Income & $1.2 \%$ & & & & & & \\
\hline Motor Vehicle License Taxes & $0.2 \%$ & $0.0 \%$ & $1.6 \%$ & & & & $0.0 \%$ \\
\hline Other Taxes & $3.1 \%$ & $0.8 \%$ & $0.9 \%$ & $0.8 \%$ & $1.5 \%$ & $0.8 \%$ & $1.3 \%$ \\
\hline $\begin{array}{l}\text { Charges and Misc. General } \\
\text { Revenue }\end{array}$ & $27.9 \%$ & $9.7 \%$ & $13.2 \%$ & $12.0 \%$ & $16.8 \%$ & $9.1 \%$ & $22.5 \%$ \\
\hline Current Charges & $18.1 \%$ & $6.0 \%$ & $8.9 \%$ & $9.0 \%$ & $11.4 \%$ & $6.1 \%$ & $15.9 \%$ \\
\hline Education & $0.2 \%$ & $0.8 \%$ & $0.6 \%$ & $0.9 \%$ & $0.5 \%$ & $0.7 \%$ & \\
\hline School Lunch Sales (gross) & $0.1 \%$ & $0.7 \%$ & $0.3 \%$ & $0.6 \%$ & $0.4 \%$ & $0.6 \%$ & \\
\hline Hospitals & $2.6 \%$ & $0.1 \%$ & $1.2 \%$ & $1.1 \%$ & & & \\
\hline Highways & $0.4 \%$ & $0.0 \%$ & $0.0 \%$ & $0.0 \%$ & & & $0.1 \%$ \\
\hline Airports & $1.6 \%$ & $0.0 \%$ & $0.9 \%$ & $0.1 \%$ & $1.0 \%$ & $0.0 \%$ & $1.6 \%$ \\
\hline Parking Facilities & $0.4 \%$ & $0.2 \%$ & $0.1 \%$ & $0.2 \%$ & $0.5 \%$ & $0.1 \%$ & $1.0 \%$ \\
\hline Sea/Inland Port Facilities & $0.3 \%$ & & $0.1 \%$ & $0.0 \%$ & & $0.1 \%$ & \\
\hline Parks and Recreation & $1.1 \%$ & $0.6 \%$ & $0.4 \%$ & $0.3 \%$ & $0.4 \%$ & $0.5 \%$ & $0.5 \%$ \\
\hline Housing and Comm. Dev. & $0.6 \%$ & $0.1 \%$ & $0.0 \%$ & $0.1 \%$ & & $0.2 \%$ & \\
\hline Sewerage & $6.3 \%$ & $1.9 \%$ & $3.0 \%$ & $4.2 \%$ & $5.1 \%$ & $2.4 \%$ & $8.1 \%$ \\
\hline Solid waste Management & $2.0 \%$ & $0.8 \%$ & $0.3 \%$ & $0.5 \%$ & $1.1 \%$ & $0.2 \%$ & $0.6 \%$ \\
\hline Other Charges & $2.6 \%$ & $1.6 \%$ & $2.2 \%$ & $1.7 \%$ & $2.7 \%$ & $2.0 \%$ & $4.0 \%$ \\
\hline Miscellaneous General Rev. & $9.8 \%$ & $3.7 \%$ & $4.3 \%$ & $3.0 \%$ & $5.4 \%$ & $3.0 \%$ & $6.6 \%$ \\
\hline Interest Earnings & $0.6 \%$ & $0.3 \%$ & $0.0 \%$ & $0.1 \%$ & $0.0 \%$ & $0.0 \%$ & $0.5 \%$ \\
\hline Special Assessments & $0.4 \%$ & $0.1 \%$ & $0.0 \%$ & $0.0 \%$ & $0.3 \%$ & $0.0 \%$ & $0.0 \%$ \\
\hline Sale of Property & $4.8 \%$ & $1.8 \%$ & $2.4 \%$ & $1.3 \%$ & $2.2 \%$ & $1.5 \%$ & $2.6 \%$ \\
\hline Other Misc. General Rev. & $4.0 \%$ & $1.5 \%$ & $1.9 \%$ & $1.6 \%$ & $2.8 \%$ & $1.5 \%$ & $3.4 \%$ \\
\hline
\end{tabular}

Source: U.S. Bureau of the Census, "Local Summary Tables by Type of Government and State: 2001-02".

Note: Census government types "municipal" and "township" are combined. Blank = none; $0=$ less than $\$ 0.50$ per capita.

*Chance of very small errors since township to municipal transfers has not been netted out. 


\section{Cyclical Links between Property Taxes and State Aid}

Property taxes and state aid-the two largest sources of revenue for local government—are linked both explicitly and implicitly. They are linked explicitly because state aid formulas usually take the capacity of local governments to collect property taxes into account. They are linked implicitly because local officials look first to state aid, which comes to them at lower political cost, and second to property taxes, which their constituents remind them are painful. State aid is a revenue source largely outside the control of local policy makers. There are limitations on local property tax collections, but generally there is local choice in setting their level. This section looks at the relationship between changes in state aid and changes in property tax collections-in particular, at evidence across states from the beginning of this decade.

Fluctuations in economic activity affect income and consumption and thus tax collections. Just after the recession year of 2001, state tax revenue experienced a severe decline across the country. States responded to the fiscal pressure in many ways, including by cutting aid to local government or restricting any increases. ${ }^{8}$ Local governments were under pressure to maintain services in the face of these restrictions, and some seem to have done so with above-trend increases in property taxes.

Dye and Reschovsky (2007) look at whether local governments substituted increases in local property taxes for decreases in state aid for the 2002-2004 period. Those authors show that in almost half the states, real state aid per capita fell from 2002 to 2004, and that

\footnotetext{
${ }^{8}$ Fox (2003) attempts to explain the severity of the decline in state revenues relative to the fall in income, while Kalambokidis and Reschovsky (2005) document the cuts in state aid.
} 
real property tax collections per capita increased over the same period, with only a few exceptions.

Table 11 shows Dye and Reschovsky's figures for the New England states. The case of Massachusetts is consistent with their hypothesis that local governments largely offset decreases in state aid with increases in property taxes. Maine's and New Hampshire's small rates of increase in state aid might be viewed as cuts relative to a trend of real increases over time. The other New England states do not seem to support the offset hypothesis. However, the simple comparison in the table does not control for other determinants of changes in property tax.

Table 11: Local Government Real Property Taxes and State Aid per capita by State, Fiscal Years 2002 and 2004

\begin{tabular}{|l|c|c|c|c|}
\hline \multicolumn{1}{|c|}{ State } & \multicolumn{2}{|c|}{ Property Tax Collections } & \multicolumn{2}{c|}{$\begin{array}{c}\text { Intergovernmental Aid } \\
\text { from State }\end{array}$} \\
\hline & $\begin{array}{c}\text { Per capita } \\
2002 \\
\text { (in 2004 dollars) }\end{array}$ & $\begin{array}{c}\text { Percent change } \\
2002-04\end{array}$ & $\begin{array}{c}\text { Per capita } \\
2002 \\
\text { (in 2004 } \\
\text { dollars) }\end{array}$ & $\begin{array}{c}\text { Percent change } \\
2002-04\end{array}$ \\
\hline Connecticut & $\$ 1,821$ & $6.8 \%$ & $\$ 963$ & $4.9 \%$ \\
\hline Maine & $\$ 1,509$ & $3.5 \%$ & $\$ 843$ & $0.9 \%$ \\
\hline Massachusetts & $\$ 1,428$ & $7.3 \%$ & $\$ 1,313$ & $-6.9 \%$ \\
\hline New Hampshire & $\$ 1,374$ & $13.5 \%$ & $\$ 1,009$ & $0.2 \%$ \\
\hline Rhode Island & $\$ 1,435$ & $13.4 \%$ & $\$ 809$ & $13.3 \%$ \\
\hline Vermont & $\$ 738$ & $9.6 \%$ & $\$ 1,426$ & $4.5 \%$ \\
\hline
\end{tabular}

Source: Dye and Reschovsky 2007, Tables 1 and 2.

Table 12 (page 24) presents Dye and Reschovsky’s data for just local school districts in New England states. Dependent school districts-which, as noted, are an important part of municipal government in the region-have been assigned a pro rata share of municipal 
property taxes. The table shows that five of six states cut real school aid per capita, making the hypothesized negative relationship with property taxes more apparent.

Table 12: School District Real Property Taxes and State Aid per capita by State, Fiscal Years 2002 and 2004

\begin{tabular}{|l|c|c|c|c|}
\hline \multirow{2}{*}{ State } & \multicolumn{2}{|c|}{ Property Tax Collections } & \multicolumn{2}{c|}{$\begin{array}{c}\text { Intergovernmental Aid } \\
\text { from State }\end{array}$} \\
\hline & $\begin{array}{c}\text { Per capita } \\
2002 \\
\left(\begin{array}{c}\text { in 2004 } \\
\text { dollars) }\end{array}\right.\end{array}$ & $\begin{array}{c}\text { Percent change } \\
2002-04\end{array}$ & $\begin{array}{c}\text { Per capita } \\
2002 \\
\text { (in 2004 } \\
\text { dollars) }\end{array}$ & $\begin{array}{c}\text { Percent change } \\
2002-04\end{array}$ \\
\hline Connecticut & $\$ 1,039$ & $14.9 \%$ & $\$ 756$ & $-4.7 \%$ \\
\hline Maine & $\$ 744$ & $3.5 \%$ & $\$ 692$ & $-4.4 \%$ \\
\hline Massachusetts & $\$ 864$ & $3.8 \%$ & $\$ 765$ & $-3.6 \%$ \\
\hline New Hampshire & $\$ 600$ & $22.4 \%$ & $\$ 778$ & $-4.2 \%$ \\
\hline Rhode Island & $\$ 799$ & $6.7 \%$ & $\$ 665$ & $3.0 \%$ \\
\hline Vermont & $\$ 293$ & $18.2 \%$ & $\$ 1,306$ & $-1.2 \%$ \\
\hline
\end{tabular}

Source: Dye and Reschovsky 2007, Tables 4 and 5.

Note: Property taxes are allocated to dependent school districts.

Table 13 (page 25) relies on more detailed data available for Massachusetts alone to again show this negative relationship. Note the sharp decline in state aid in 2003 and again in 2004 , and the corresponding above-trend increases in property taxes. The last row of the table provides some additional evidence on a question raised earlier: What has been happening to the use of charges and fees by municipal governments in recent years? 
Table 13: Annual Percent Change in Selected Revenue Sources for Municipalities in Massachusetts (by Fiscal Year)

\begin{tabular}{|l|c|c|c|c|c|c|c|c|c|c|}
\hline & 1996 & 1997 & 1998 & 1999 & 2000 & 2001 & 2002 & 2003 & 2004 & 2005 \\
\hline Total & 5.8 & 6.3 & 6.0 & 6.7 & 6.3 & 6.7 & 5.7 & 2.5 & 2.7 & 4.7 \\
\hline Property Taxes & 3.9 & 4.0 & 4.8 & 4.6 & 5.2 & 5.9 & 6.4 & 6.1 & 6.1 & 5.2 \\
\hline State Aid & 9.5 & 9.5 & 11.1 & 9.9 & 8.4 & 7.3 & 4.5 & -2.9 & -5.2 & 4.4 \\
\hline $\begin{array}{l}\text { Fees and } \\
\text { Charges }\end{array}$ & 5.0 & 6.5 & 4.1 & 7.4 & 5.6 & 6.6 & 3.7 & 4.1 & 4.9 & 5.4 \\
\hline
\end{tabular}

Source: Municipal Finance Task Force 2005, “Municipal Finance Data: Statistical Tables.”

Dye and Reschovsky move past simple comparisons like those in Tables 11 to 13 and perform multiple regression analysis on a 49-state sample with control variables for other determinants of cross-state variations in the growth of property taxes. For school districts, Dye and Reschovsky find a significant negative relationship between changes in state aid and changes in property taxes, consistent with Table 12 . Their estimates suggest that, on average, local governments have the flexibility to offset a one-dollar cut in school aid with a 25-cent increase in property tax collections.

Dye and Reschovsky interpret these results as providing "strong evidence of the strength and resiliency of the property tax." They go on to note:

"Not only is the local property tax base much more stable with respect to cyclical influences than the bases of the state income or sales tax, but local property tax rates appear to be, in most states, sufficiently flexible so that local property tax revenues can be varied so as to provide a counter-cyclical buffer to changes in state aid. In essence, our results seem to reinforce that conclusion that the local property tax plays a critical role in our federal system." 


\section{Property Tax Limitations}

Property taxes have their advantages, but they also have negative attributes that provoke popular resistance and lead many states to limit their use. Limits on local property taxes are the most prominent of a larger list of constraints on the taxing and spending of both local and state governments. According to Mullins and Wallin (2004), "Forty-six states have some form of constitutional or statutory statewide limitation on the fiscal behavior of their units of local government." Table 14 presents the caps for the three New England states that limit local property taxes.

Table 14: Statewide Property Tax Limitations on Municipal Governments (no limit if blank)

\begin{tabular}{|l|l|c|c|}
\hline \multicolumn{1}{|c|}{$\begin{array}{c}\text { State } \\
\text { (year imposed) }\end{array}$} & Limit on Tax Rate & $\begin{array}{c}\text { Limit on Revenue } \\
\text { Growth }\end{array}$ & $\begin{array}{c}\text { Limit on Increase } \\
\text { in Assessment }\end{array}$ \\
\hline Connecticut & & $\begin{array}{c}2.75 \% \\
\text { of prior year }\end{array}$ & Local option \\
\hline Maine (2005) & $\begin{array}{c}2.5 \% \\
\text { of prior year }\end{array}$ & \\
\hline Massachusetts (1980) & & & \\
\hline New Hampshire & & $\begin{array}{c}5.5 \% \text { to } 4.0 \% * \\
\text { of prior year }\end{array}$ & \\
\hline $\begin{array}{l}\text { Rhode Island (1985 and } \\
\text { 20o6) }\end{array}$ & & & \\
\hline Vermont & & & \\
\hline
\end{tabular}

Source: Mullins and Wallin 2004; Anderson 2006; Baer 2006.

Note: All have exceptions or more detailed rules not shown here.

*Was 5.5 percent to fiscal year 2007. A 2006 amendment lowers the cap in one-quarter percent increments, reaching 4.0 percent in 2013 and thereafter (Setze 2006).

Proposition 21/2 has been in effect in Massachusetts since 1980. In that state, a local government's total tax revenues cannot increase by more than 2.5 percent of the prior year's amount, with exceptions for new property and override by local referendum. The overall tax 
rate for local governments also cannot exceed 2.5 percent of the full value of all taxable property in the jurisdiction (Baer 2006).

Rhode Island limits local governments to increases of 5.5 percent over prior-year revenues. A recent change will tighten this cap each year until it reaches 4.0 percent in 2013. The state allows exceptions for debt, emergencies, and losses from other revenue sources (Baer 2006).

In 2005, Maine joined the property tax limitation club with a 2.75 percent limit on year-to-year revenue growth, with an exception for new property. The rate limit could be lower if personal income growth in the state is very low, and higher if the state's ranking in total taxes relative to personal income declines significantly (Baer 2006).

As noted, property taxes are the largest revenue source for local governments nationwide, and particularly in New England. Statewide limits on property tax revenues will heighten the importance of state aid to municipal governments, and their access_-or lack thereof-to revenue sources other than property taxes. ${ }^{9}$

\section{Looking Ahead: The Impact of an Aging Society on State and Local Budgets}

There is, in my view, reason to be concerned-even pessimistic-about future pressures on state and local budgets. The same demographic and health care cost pressures that threaten federal budgets will also affect state and local governments.

The Congressional Budget Office (2005) projects that to maintain spending under existing program rules, the share of gross domestic product devoted to Social Security would have to rise by 1.8 percentage points by 2030. Even more dramatically, the budget office

\footnotetext{
${ }^{9}$ Note that the impact of a state limit on property taxes depends on its exact wording (Brome and Saas 2006).
} 
projects that the nation will need to devote another 5.0 percent of GDP to Medicare and Medicaid by 2030. Think of it: in just 25 years, a claim on an extra 6.8 percent of everything that the U.S. economy produces to maintain these three federal programs!

Four factors drive these projections. Health care costs have risen far in excess of other costs for decades, and are expected to do so in the future. The other three factors are demographic. Improvements in longevity mean that recipients collect benefits for more years. Low fertility rates mean that fewer new taxpayers will come of working age and support retirees by producing output and paying a share of it in taxes. Finally, the coming retirement of the baby boomers—-the large age cohort born between 1946 and 1964, which will start collecting Social Security benefits in 2008 and become eligible for Medicare in 2011 — will further compound the pressure on both the tax and spending sides of the budget. As noted, the same demographic and health care cost factors putting serious longterm pressure on the federal budget also affect state and local governments.

States differ considerably in the age distribution of their populations, and thus the severity of these changes. Table 15 (page 28) shows the age distribution of the population in each New England state in 2000. The age groups can be roughly labeled as preschool age (0-4), school age (5-19), college age (20-24), working age (25-64), and retirement age (65 and up). Overall, 12.5 percent of the population is age 65 or older. Maine and Rhode Island, at 14.5 percent, have considerably more older citizens, while New Hampshire has slightly fewer. 
Table 15: Share of 2000 Census Population in Selected Age Groups by State

\begin{tabular}{|l|c|c|c|c|c|}
\hline & Age O-4 & Age 5-19 & Age 20-24 & Age 25-64 & Age 65 up \\
\hline United States & $6.8 \%$ & $21.8 \%$ & $6.7 \%$ & $52.2 \%$ & $12.4 \%$ \\
\hline Connecticut & $6.6 \%$ & $20.6 \%$ & $5.5 \%$ & $53.5 \%$ & $13.8 \%$ \\
\hline Maine & $5.5 \%$ & $20.8 \%$ & $5.5 \%$ & $53.8 \%$ & $14.4 \%$ \\
\hline Massachusetts & $6.3 \%$ & $20.1 \%$ & $6.4 \%$ & $53.7 \%$ & $13.5 \%$ \\
\hline New Hampshire & $6.1 \%$ & $21.7 \%$ & $5.6 \%$ & $54.6 \%$ & $12.0 \%$ \\
\hline Rhode Island & $6.1 \%$ & $20.9 \%$ & $6.9 \%$ & $51.7 \%$ & $14.5 \%$ \\
\hline Vermont & $5.6 \%$ & $21.7 \%$ & $6.2 \%$ & $53.7 \%$ & $12.7 \%$ \\
\hline
\end{tabular}

Source: Calculated from U.S. Census 2005, and taken from Dye 2007, "Supplemental Tables."

Table 16 presents the same age-group shares from the Census Bureau's population projections for 2030. Note the projected dramatic increase in the retirement-age population. In the United States as a whole, the 65-and-up age group is expected to expand from 12.4 to 19.7 percent of the population. The projected increase in the elderly share of the population in the New England states is even more dramatic. Note, in particular, the projected elderly shares in 2030 of 26.5 percent in Maine and 24.4 percent in Vermont.

Table 16: Share of Projected Population in 2030 in Selected Age Groups by State

\begin{tabular}{|l|c|c|c|c|c|}
\hline & Age O-4 & Age 5-19 & Age 20-24 & Age 2--64 & Age 65 up \\
\hline United States & $6.7 \%$ & $19.5 \%$ & $6.4 \%$ & $47.8 \%$ & $19.7 \%$ \\
\hline Connecticut & $6.0 \%$ & $18.6 \%$ & $5.4 \%$ & $48.5 \%$ & $21.5 \%$ \\
\hline Maine & $4.6 \%$ & $15.4 \%$ & $4.4 \%$ & $49.1 \%$ & $26.5 \%$ \\
\hline Massachusetts & $6.1 \%$ & $18.4 \%$ & $6.2 \%$ & $48.4 \%$ & $20.9 \%$ \\
\hline New Hampshire & $5.7 \%$ & $18.1 \%$ & $5.0 \%$ & $49.8 \%$ & $21.4 \%$ \\
\hline Rhode Island & $5.7 \%$ & $19.0 \%$ & $6.1 \%$ & $47.9 \%$ & $21.4 \%$ \\
\hline Vermont & $4.9 \%$ & $17.1 \%$ & $5.3 \%$ & $48.3 \%$ & $24.4 \%$ \\
\hline
\end{tabular}

Source: Calculated from U.S. Census 2005, and taken from Dye 2007, "Supplemental Tables." 
The burden of supporting a larger elderly population falls primarily on people of working age, who are producing the output that must be taxed, transferred, or traded for financial assets to support consumption of goods and services by the elderly. Table 17 shows the old-age dependency ratio- the number of people aged 65 and older divided by the number of people aged 25 to 64 .

Table 17: Old-Age Dependency Ratio by Decade and State (Age 65+ / Age 25-64)

\begin{tabular}{|l|c|c|c|c|}
\hline & $\begin{array}{c}\mathbf{2 0 0 0} \\
\text { Census }\end{array}$ & $\begin{array}{c}\mathbf{2 0 1 0} \\
\text { Projection }\end{array}$ & $\begin{array}{c}\mathbf{2 0 2 0} \\
\text { Projection }\end{array}$ & $\begin{array}{c}\mathbf{2 0 3 0} \\
\text { Projection }\end{array}$ \\
\hline United States & $23.8 \%$ & $24.6 \%$ & $31.8 \%$ & $41.1 \%$ \\
\hline Connecticut & $25.8 \%$ & $26.9 \%$ & $33.5 \%$ & $44.4 \%$ \\
\hline Maine & $26.7 \%$ & $27.9 \%$ & $38.9 \%$ & $54.0 \%$ \\
\hline Massachusetts & $25.2 \%$ & $25.3 \%$ & $32.4 \%$ & $43.1 \%$ \\
\hline New Hampshire & $21.9 \%$ & $22.9 \%$ & $31.8 \%$ & $43.0 \%$ \\
\hline Rhode Island & $28.1 \%$ & $26.6 \%$ & $33.1 \%$ & $44.6 \%$ \\
\hline Vermont & $23.7 \%$ & $25.9 \%$ & $37.4 \%$ & $50.6 \%$ \\
\hline
\end{tabular}

Source: Calculated from U.S. Census 2005, and taken from Dye 2007, "Supplemental Tables."

The increase in the dependency ratio projected for the next three decades is remarkably large. In the United States overall, the dependency ratio rises from 23.8 to 41.1 percent-an increase of almost three-quarters. In both Vermont and Maine, the dependency ratio more than doubles, to more than 50 percent! Note that the increase in the dependency ratio is modest from 2000 to 2010 (even negative in Rhode Island), large from 2010 to 2020, and very large from 2020 to 2030. The demographic shift to an older population distribution has started, but it is going to get much more painful for those who 
pay for government services to the elderly. America is aging, and state and local policy makers need to pay attention to that inexorable trend.

\section{State and Local Budget Pressures}

Awareness that America is aging is dawning, but the public, especially, seems little aware of the many implications. Policy makers and analysts are starting to realize that the aging trend affects more than just the Social Security program. ${ }^{10}$

Medicare and Medicaid. The good news for states is that Medicare is a purely federal program. Medicaid, however, is a joint federal-state program with a cost-matching formula. Federal cost shares in New England range from 63 percent in Maine, to 59 percent in Vermont, to 52 percent in Rhode Island, to 50 percent in the higher-income states, which include New Hampshire, Massachusetts, and Connecticut (U.S. Department of Health and Human Services 2005).

State legislators and governors have become acutely aware of the pressure on state budgets from the Medicaid program, because they have had to share the pain of growing Medicaid costs in recent decades. Whether they are aware of projections of just how much worse the situation might get in the future is unclear. ${ }^{11}$ If the federal government responds to the enormous pressure on its own budget by decreasing match rates, restricting other state aid, or tightening requirements, the pressure on state budgets could be even greater. Retiree medical insurance. Employees of state and local governments generally have good health insurance coverage promised for their retirement. State and local governments

\footnotetext{
${ }^{10}$ This section draws on Dye 2007. See also Wallace 1995, Menchik 2002, and U.S. GAO 2007.

${ }^{11}$ See Marton and Wildasin 2007 for projections and analysis of future state Medicaid costs.
} 
have long been required to provide actuarial estimates of the present value of future pension obligations and, to an extent, to prefund those obligations (more on this below). Until now, however, there was no corresponding requirement to account for or prefund other post-employment benefits, such as future retiree health care costs.

The Government Accounting Standards Board recently promulgated new standards, called GASB-45, requiring that other post-employment benefit costs be accounted for and amortized (GASB 2004). The new requirements phase in from 2007 to 2009, so the extent of this previously unaccounted-for and unfunded liability will be revealed over the next several years.

There is reason to believe that GASB-45 could put considerable pressure on many state and local budgets: "Based on early estimates, issuers generally are reporting [annual required contributions] of anywhere from two to 10 times the current pay-as-you-go amount" (Fitch Ratings 2007). Brady's (2007) estimates for Maine are in that range: "If the state were to implement GASB 45 for fiscal year 2007, the state's additional reported cost increase from 2006 to 2007 could be anywhere from 302 to 569 percent.”

Retiree pensions. As noted, state and local governments are required to account for future pension liabilities. However, most states have not fully funded those prospective obligations. In a study of state retirement systems for fiscal year 2005, Standard \& Poor's (2007) found an average funding ratio_-assets as a share of the actuarial value of future liabilities_of 82 percent. Connecticut (58 percent) and Rhode Island (59 percent) are among the states with the lowest funding ratios. New Hampshire (66 percent), Massachusetts (73 percent), and Maine (73 percent) are below average. Vermont (94 percent) is above average but still less than fully funded. When public employees from the 
baby boom generation actually retire, as they are starting to do, the unfunded obligations will become current, and put direct pressure on other items in the budget. ${ }^{12}$

Education spending. Tables 15 and 16 set up the point that the increasing elderly share of the population is bad news for state and local government. However, there is good news for the state and local government sector in those tables, too.

A comparison of Tables 15 and 16 shows a projected decline in school-age and college-age populations in the United States and the New England states over the next 20 or 30 years. This will affect demand for educational services. ${ }^{13}$ As noted, there is evidence from the beginning of this decade that cuts in state revenues led to significant cuts in state aid to local public education (Dye and Reschovsky 2007). As states experience pressure on their budgets from demographic and health care cost trends, local school districts should be concerned.

Income taxes. Five New England states have a broad-based individual income tax, while New Hampshire has a narrow-based tax on just interest and dividends. It is hard to predict what will happen to state income tax collections as the population ages. However, unlike some states, the five New England states do tax pension income.

Sales taxes. New England states other than New Hampshire have state sales taxes. The impact of an aging population on sales tax revenues will depend on age-specific expenditure patterns and expenditure-specific exemptions from the sales tax base. The exemption of medical services and prescription drugs from the sales tax in most states suggests that revenues may decline as the population ages (Menchik 2002).

\footnotetext{
${ }^{12}$ See Giertz and Papke 2007 for more on public pensions and state budgets.

${ }^{13}$ See Murray, Rueben, and Rosenberg 2007 for analysis of this topic.
} 
Property taxes. The mainstay of local government finance in New England is the property tax. Many states give age-conditioned homestead exemptions from the property tax, which would affect local tax collections as the population ages. Some states offer ageand income-conditioned property tax "circuit breakers" — tax relief-which will affect state tax collections as the population ages.

Table 18 shows the key eligibility rules for homestead exemptions and circuit breakers for the New England states. Vermont offers no age-based property tax relief. Only Massachusetts and New Hampshire offer statewide homestead relief for all elderly, and in New Hampshire the eligibility requirements are quite limiting.

Table 18: Age-Based Property Tax Relief Programs in 2005 with Key Eligibility Rules

\begin{tabular}{|c|c|c|}
\hline & Homestead Exemption & State Circuit Breaker \\
\hline Connecticut & $\begin{array}{l}\text { Local option } \\
\text { if age } \bullet 65 \\
\end{array}$ & $\begin{aligned} \text { If age } \bullet & 65 \\
\text { and income } & <\$ 33,900\end{aligned}$ \\
\hline Maine & $\begin{array}{c}\text { Only if veteran } \\
\text { and age } \bullet 62\end{array}$ & $\begin{array}{c}\text { If age } \bullet 62 \\
\text { and income }<\$ 15,300\end{array}$ \\
\hline Massachusetts & $\begin{array}{c}\text { If age } \bullet 70 \\
\text { additional local option }\end{array}$ & $\begin{array}{c}\text { If age } \bullet 65 \\
\text { and income }<\$ 67,000\end{array}$ \\
\hline New Hampshire & $\begin{array}{c}\text { If age } \bullet 65 \\
\text { and residency } \bullet 5 \text { years } \\
\text { and income }<\$ 20,400 \\
\text { and assets }<\$ 35,000\end{array}$ & Not age-based \\
\hline Rhode Island & Some local option & If income $<\$ 30,000$ \\
\hline Vermont & Not age-based & Not age-based \\
\hline
\end{tabular}

Source: Baer 2006.

Increases in property taxes or local overrides of property tax limits often require approval of local voters. An aging population may have different preferences for local government services and the property taxes that pay for them. There is evidence, for 
example, that voting patterns for school levies vary by age. However, Murray, Rueben, and Rosenberg (2007) review that evidence and report that while some studies find the simple result that the old vote no, others find more complicated age-based voting patterns that depend on state aid formulas, tax limitation rules, and tax relief features.

This evidence reveals some fairly direct effects of an aging population on different types of state and local expenditures and revenues. There are also some important indirect effects. One source of indirect pressure will occur across budget items for a state or municipality. There may be no direct link between the age distribution of the population and, say, infrastructure spending. However, growing pressure to fund medical care will make it harder to pass a budget with more funding for bridge repairs.

A second source of indirect pressure is more relevant to this analysis of municipal revenue sources. In a system of fiscal federalism, serious pressures on federal budgets will affect grants to state and local governments. Such pressures may also lead to devolution of responsibility for certain government services, and to federal preemption of revenue sources traditionally used by states. Pressure on state budgets, in turn, will trigger pressure on local governments.

\section{Conclusion}

The previous section examined the looming fiscal pressures from an aging population-a topic that is both under recognized and enormously important. We can also anticipate that already identified problems will continue. And we should look ahead to potential policy solutions to both the old and new concerns. 
Anyone can forecast continuing pressure to "do something" about high property taxes. Every New England state is hearing arguments from political groups seeking new or tighter limits on property taxes. On the other side are pressures to "do something" about the problems municipal governments are already having maintaining service levels.

A recent article on fiscal stress in Massachusetts municipalities (Gurley 2007) enumerates—with little optimism for voter or legislative approval—a number of possible solutions. These include a local-option sales tax, other new local-option taxes, new fees, and-predict the vote on this one!-an increase in the Commonwealth's cap on property taxes from its namesake $2 \frac{1}{2}$ percent to 3 percent. $^{14}$

We can look at the recent past and expect continuing pressure for states to "do something" to help local governments maintain services, and keep property taxes, from rising by increasing state aid. The Massachusetts Taxpayers Foundation (2005) has proposed that the Commonwealth dedicate 40 percent of its revenues from sales, income, and corporate taxes to municipal aid. A careful study of the state's economy by researchers at Northeastern University (Bluestone, Clayton-Matthews, and Soule 2006) endorsed that proposal.

The issue of school finance reform is still alive in most New England states. There are pressures to use state aid to reduce disparities across locales in access to property taxes, and pressures to increase state aid to education. However, it is hard to look at the pessimistic picture I have painted of the demographic pressures on state budgets and

\footnotetext{
${ }^{14}$ In the same article, Gurley asserts and provides anecdotal evidence of "creeping government-bysubscription." However, it is hard to see a significant overall increase in municipal charges in Table 13, or from comparing Tables 10 and 8.
} 
expect state grants-in-aid to relieve municipal budget pressures. Local governments are going to have it hard.

This cautionary—even pessimistic_-view of what the future could hold for local government should not freeze us into inaction, however. Rather, I hope this scenario will give greater urgency to the need for policy responses, such as alternative revenue sources for municipal governments and changes in state aid formulas. 


\section{References}

Anderson, Nathan B. 2006. "Property Tax Limitations: An Interpretative Review." National Tax Journal, September: 685-695.

Baer, David. 2006. "State Handbook of Economic, Demographic, and Fiscal Indicators 2006.” Washington, DC: AARP Public Policy Institute. http://www.aarp.org/research/reference/statistics/d18489_fiscal.html.

Bluestone, Barry, Alan Clayton-Matthews, and David Soule. 2006. "Revenue Sharing and the Future of the Massachusetts Economy." Boston: Northeastern University, Center for Urban and Regional Policy. http://www.curp.neu.edu/pdfs/MMA_RevenueSharing.pdf.

Brady, Steffanie. 2007. "GASB 45 and Other Post-Employment Benefit Promises: The Fog Is Clearing." Policy Brief 07-7. Boston: Federal Reserve Bank of Boston, New England Public Policy Center. http://www.bos.frb.org/economic/neppc/briefs/2007/briefs077.pdf.

Brome, Heather, and Darcy Rollins Saas. 2006. "Reading the Fine Print: How Details Matter in Tax and Expenditure Limitations." Research Report 06-3. Boston: Federal Reserve Bank of Boston, New England Public Policy Center. http://www.bos.frb.org/economic/neppc/researchreports/2006/rr0603.htm.

Congressional Budget Office. 2005. "The Long-Term Budget Outlook.” Washington, DC: U.S. Congress. http://cbo.gov/ftpdocs/69xx/doc6982/12-15-LongTermOutlook.pdf.

Dye, Richard F. 2007. "The Effect of Demographic Change on State and Local Government Budgets." Policy Forum 20:1. University of Illinois, Institute of Government and Public Affairs. Chicago and Urbana, IL. http://www.igpa.uiuc.edu/. See also supplementary tables at http://www.igpa.uillinois.edu/lib/data/pdf/PolicyForum20-1Supplemental.pdf.

Dye, Richard F., and Andrew Reschovsky. 2007 (revised). "Property Tax Responses to State Aid Cuts in the Recent Fiscal Crisis." Prepared for Urban Institute conference on State and Local Finances after the Storm: Is Smooth Sailing Ahead? March.

Fitch Ratings. 2007. "Old Promises, Emerging Bills: Considering OPEB in Public Finance Ratings.” U.S. Public Finance, Tax Supported Special Report, March 22. New York. http://www.pebc.ca.gov/images/files/OldPromises.pdf.

Fox, William F. 2003. "Three Characteristics of Tax Structures Have Contributed to the Current State Fiscal Crises." State Tax Notes, August 4, 375-384. 
Giertz, J. Fred, and Leslie E. Papke. 2007. "Public Pension Plans: Myths and Realities for State Budgets." National Tax Journal 60(2):305-323.

Gottlob, Brian, and Daphne A. Kenyon. 2005. "Dollars Diverted: Taking a Hard Look at Education Finance Reform in New Hampshire." State Tax Notes, March 21, 861ff.

Government Accounting Standards Board (GASB). 2004. "GASB Issues Statement That Addresses Employer Reporting of Postemployment Benefits Other Than Pensions." News Release, August 2. Washington, DC. http://www.gasb.org/news/nr080204.html.

Gurley, Gabrielle. 2007. "Municipal Meltdown." CommonWealth, Fall, 44-58.

Kalambokidis, Laura, and Andrew Reschovsky. 2005. "States' Responses to the Budget Shortfalls of 2001-2002." Challenge, January-February, 78-93.

Kenyon, Daphne A. 2003. "Are State Governments Encroaching on the Local Property Tax?” State Tax Notes, June 30,1149-1152.

Marton, James, and David E. Wildasin. 2007. "Medicaid Expenditures and State Budgets: Past, Present, and Future.” National Tax Journal 60(2): 278-304.

Massachusetts Taxpayers Foundation. 2005. "MTF Calls on State to Dedicate 40 Percent of Tax Revenues to Local Aid, Benchmark Municipal Costs." News Release, November 22. Boston.

Menchik, Paul L. 2002. "Demographic Change and Fiscal Stress in Michigan." State Tax Notes, July 15, 219-226.

Mullins, Daniel R., and Bruce A. Wallin. 2004. "Tax and Expenditure Limitations: Introduction and Overview." Public Budgeting \& Finance, Winter, 2-15.

Municipal Finance Task Force [of Massachusetts]. 2005. "Local Communities at Risk: Revisiting the Fiscal Partnership Between the Commonwealth and Cities and Towns.”

Murray, Matthew N. 2006. "A Profile of the Maine State and Local Tax System." Background paper for Charting Maine's Future: An Action Plan for Promoting Sustainable Prosperity and Quality Places, Brookings Institution, Metropolitan Policy Program, October. http://www3.brookings.edu/metro/pubs/maine/profile.pdf.

Murray, Sheila E., Kim Rueben, and Carol Rosenberg. 2007. "State Education Spending: Current Pressures and Future Trends." National Tax Journal 60(2):325-345.

Nagowski, Matthew Peter. 2007. "The Fiscal Capacity of New England.” Policy Brief 07-4. Boston: Federal Reserve Bank of Boston, New England Public Policy Center. 
Sass, Darcy Rollins. 2006. "School Finance in Vermont: Balancing Equal Education and Fair Tax Burdens.” State Tax Notes, April 2, 33-42.

Setze, Karen. 2006. "Rhode Island Governor Approves Lowering Local Property Tax Cap." State Tax Notes, July 24, 206.

Standard \& Poor's. 2007. “Improved U.S. State Pension Funding Levels Could Be on the Horizon.” Public Finance Commentary. New York. http://www.nasra.org/resources/S\&Pstatefundinglevels0702.pdf.

U.S. Bureau of the Census. 2005. "State Interim Population Projections by Age and Sex." Washington, DC.

http://www.census.gov/population/www/projections/projectionsagesex.html.

U.S. Department of Health and Human Services, Assistant Secretary for Planning and Evaluation. 2005. "Federal Medical Assistance Percentages, Fiscal Year 2007 Table." Washington, DC. http://aspe.hhs.gov/health/fmap.htm.

U.S. Government Accountability Office (GAO). 2007. "State and Local Governments: Persistent Fiscal Challenges Will Likely Emerge within the Next Decade." GAO07-1080SP. Washington, DC. http://www.gao.gov/new.items/d071080sp.pdf.

Urban Institute-Brookings Institution Tax Policy Center. State \& Local Government Finance Data Query System. Data from U.S. Bureau of the Census, Annual Survey of State and Local Government Finances; Government Finances, vol. 4; and Census of Governments, various years. Washington, DC. http://www.taxpolicycenter.org/slfdqs/pages.cfm.

Wallace, Sally. 1995. "The Effects of Demographic and Economic Changes on State and Local Budgets.” Washington, DC: Finance Project.

Wallin, Bruce A. 2005. "Budgeting for Basics: The Changing Landscape of City Finances." Washington, DC: Brookings Institution, Metropolitan Policy Program. www.brookings.edu/metro/pubs/20050823_budgetingbasics.htm.

Ylimaz, Yesim, Sonya Hoo, Matthew Nagowski, Kim Rueben, and Robert Tannenwald. 2006. "Measuring Fiscal Disparities across the U.S. States: A Representative Revenue System/Representative Tax System Approach, Fiscal Year 2002." NEPPC Working Paper 06-2. Boston: Federal Reserve Bank of Boston, New England Public Policy Center. 